\title{
THE METHODS OF FINANCING CITY PLANNING PROJECTS ${ }^{1}$
}

\author{
BY NELSON P. LEWIS ${ }^{2}$ \\ New York
}

$I^{N}$ $\mathrm{N}$ CONSIDERING methods of financing city planning projects it is important that a clear idea be had as to what city planning projects mean. In discussing this subject the term will be broadly construed and will not be confined to the more spectacular plans, such as the creation of civic centers, the location of important public buildings, the development of a system of parks and parkways and the working out of a consistent scheme of restrictions as to the use of public and private property. City planning projects will be deemed to include the entire development and carrying out of the structural plan of a city; the location of transportation lines connecting the city with other parts of the country; provision for adequate terminal facilities for and connections between such lines; the determination of the main traffic arteries, so located as to permit the development of an economical scheme of main drainage and to afford direct, though not necessarily straight, lines of communication between different parts of the city and with the contiguous territory; the establishment of secondary lines of communication tributary to the main lines and reaching every portion of the city; the planning of residential areas in such a manner that natural features will not be destroyed, that needless expense for construction will be avoided, and that plots will be available, not only for ambitious homes with ample space, but for the more modest cottages, where the owner need not be obliged to purchase more than the necessary land or pay for the improvement of streets of a greater width than may be required to serve local needs. It will include provision for parks and playgrounds so located that they will be readily accessible, but will be so selected as to provide needed facilities for recreation with a minimum of expenditure of the public funds; the location of the chief and subordinate public buildings with due regard both for convenience and sightliness; an adequate system of transportation in the streets of the city which will insure rapid and comfortable movement between different sections of the city and will tend to distribute population and avoid congestion.

Before such comprehensive planning is undertaken there should be a well-defined policy as to the manner in which the execution of the plan is to be financed. Ambitious projects are frequently discussed, elaborate

${ }^{1}$ A paper presented at the meeting of the National Municipal League, Springfield, November 25, 1916.

${ }^{2}$ Chief engineer, New York bureau of public improvements. 
plans are made, the drawings showing them are put on exhibition and admired, and those responsible for them are complimented until some taxpayer asks the pertinent question as to what it is going to cost and how the funds are to be provided. The enthusiasm which has been developed quickly subsides. The plans are laid aside and are soon forgotten, and in due course of time another group of citizens, realizing that the town is not as attractive and convenient as it should be, inaugurates another campaign for improvement, experts are called in, other studies are made, and finally the same question is asked with the same result. Should the taxpayers be willing to provide the necessary funds to carry out one or more of the projects included in a plan made in this way, it is often found that the city lacks the power to undertake such improvements, and legislation is required. The character of this legislation is likely to be the subject of much debate and, if its provisions are finally agreed upon and its enactment is secured, it is commonly found to be so specific in its provisions that it is not adapted to the carrying out of any other project than the one in mind at the time, if, indeed, it is not specifically limited to such project.

Comprehensive and simple statutory provisions under which the city or town may develop its plan are as essential as the plan itself and, while such statutes should so be drawn as to prevent reckless expenditure during a period of enthusiasm, they should allow as large a measure of home rule and local independence as may be consistent with protection of the municipality against its own folly or unwise enthusiasm. This is usually accomplished by prohibitions against the incurring of indebtedness in excess of a fixed percentage of the assessed value of taxable real estate, against a rate of taxation exceeding a certain percentage of such assessed values and against special assessments which shall be more than a certain proportion of the assessed or actual value of the property which may be assessed.

Improvements of the kind under consideration may be classified as those which are strictly local in their benefit,- and by the word "local" is meant those which are designed to serve the needs of the abutting property or that in the immediate neighborhood,--those which involve both local benefit and a certain degree of general benefit to the entire community and those which are almost wholly of general benefit, although they may result in an enhancement of values in the immediate vicinity, while it must be admitted that in some instances they may tend to depreciate local values.

In small towns the creation of a public square about which the business of the community will center will be an improvement of general public benefit and it may reasonably be contended that the town itself should meet the expense. The most valuable property will be that fronting upon or in the immediate vicinity of this public square, so that, if its creation 
or improvement results in special benefit to the surrounding property, that property will bear a correspondingly larger part of the burden. As the town grows and as other main streets or other centers of activity are needed there will still be some general benefit, but a large degree of local benefit. The effect upon the property in their neighborhood will be proportionately greater and more exclusive than in the case of the first center or the one main street, but the entire community will still feel the benefit of the improvement and the town can still afford to contribute a substantial portion of the expense. As the city grows every improvement which may be undertaken will involve more local and less general benefit and the time will soon come when the city as a whole is slightly, if at all, benefited by the creation and improvement of a new street or even a new public place or small park. It will be necessary to determine in each of these cases how much of the cost which is involved shall be assessed upon the property directly benefited and what proportion, if any, shall be borne by the entire city. This will require the exercise of great discretion and impartial judgment and the apportionment of the expense should be determined in a consistent manner in each instance through some board or body having a continuing existence, the members having overlapping terms, in order that there may be continuity of policy and no radical changes from year to year. If it be granted that a portion of the cost of all improvements where local benefit is involved should be assessed upon the property which will enjoy this benefit, the question which next arises is how shall the city or town meet the proportion of the cost which may be assumed by it as representing a general or community benefit. The easiest way to provide these funds is by borrowing, and the longer the term for which a loan can be made the less will be the apparent burden upon the general taxpayer. "If the next generation is to enjoy the benefit of this improvement," it is frequently argued, "why not let the next generation pay for it? We, in our wisdom, have provided it for them and have thereby contributed our share." The longer the term of the loan the less will be the rate of interest and the annual provision for the amortization of the debt when it falls due. Let us see what this means. Fifty-year bonds will doubtless carry not more than 4 or $4 \frac{1}{2}$ per cent interest. Their amortization on a 3 per cent basis will, according to generally accepted annuity tables, involve a yearly contribution of 0.89 per cent. This means that the community will ultimately pay for every $\$ 1,000$ of borrowed money the sum of $\$ 2,695$, or $\$ 53.90$ a year, in the case of $4 \frac{1}{2}$ per cent bonds; or a total of $\$ 2,445$, or at the rate of $\$ 48.90$ a year in the case of 4 per cent bonds. If the term of the loan be reduced to 15 years, $4 \frac{1}{2}$ per cent bonds, with provision for a sinking fund for their amortization, will involve the payment for each $\$ 1,000$ of $\$ 1,482$, or $\$ 98.80$ a year, while in case the loan is for the still briefer period of 10 years the public will pay for each $\$ 1,000, \$ 1,322$, or at the rate of $\$ 132.20$ 
a year. When an individual has not the cash and needs something he is often justified in borrowing the money to pay for it, but prudence would require that he see his way clear to pay off the debt within the life of the article he is to purchase. Inasmuch as the kind of improvements we are now discussing have an almost indefinite life, it may be argued that the payment of the debt can be indefinitely deferred. When, however, we consider the great number of enterprises which the modern city must undertake. the annual burden required to meet the city's obligations on long-term bonds and to maintain the city's credit will be cumulative and will in time become a very serious burden upon the taxpayers. New York city has been financing many great projects by the issue of 50-year bonds,-in some instances improvements such as pavement renewals, the life of which may be but 10 or 15 years, have been paid for in this way, - until the debt service, or the sums needed to meet interest and sinking funds, amounted to nearly 40 per cent of the annual tax budget. The city was finally obliged to adopt a pay-as-you-go policy. As by far the largest part of its bonded debt is in the form of long-term bonds issued within the last 15 years, the amount required for the debt service will decrease very slowly while the rate of taxation must increase as a result of the new policy. The people of New York have already become the posterity which it was thought should pay for the improvements they were to enjoy. Unfortunately many of those for which they are now paying have long ago disappeared, and in the case of street pavements several successive pavements on the same street have been worn out and replaced before they were paid for. A city's credit should be used sparingly and long-term bonds are justified only when the margin of borrowing capacity is ample, or to pay for improvements which may confidently be expected to become self-sustaining.

It has already been pointed out that, as a city increases in size, the creation and improvement of new streets, provision for adequate drainage, the establishment of parks and parkways and even the location and suitable grouping of public buildings will result in more local and less general benefit. Such local benefit may be considered exclusive with respect to streets of ordinary width and the sewers which will serve the abutting property. If a street be given a greater width than is required for strictly local use, the benefit will be extended, but can still be localized, while the cases are rare in which the benefit to the city-at-large will exceed that to the locality. The same is true with respect to small parks and even with respect to the location of public buildings, which are quite certain to encourage better development and enhance values in their immediate vicinity.

The fundamental principle which the writer desires to emphasize is that, wherever an improvement of any kind will result in local benefit, that fact should be recognized by the imposition of a fair proportion of the 
cost upon the property so affected, and that the owners of such property should not be enriched at the expense of the entire community and through no act of theirs, unless it be the exercise of such influence as they may possess to induce the city authorities to locate a park or undertake some other improvement in their neighborhood at the public expense. If such a policy be adopted and adhered to consistently, it will enable many towns to undertake and finance what are commonly known as city planning projects which would have to be abandoned or indefinitely postponed, or which would be out of the question if their entire cost were to be met by the city-at-large either through an issue of bonds or by general taxation. Emphasis also should be placed upon the need of a definite policy in this respect before the planning of such improvements is undertaken, as such plans, their scope and scale, will inevitably be affected by the assurance that they can be financed. While this is a reversal of the usual order of procedure, it must be conceded that in public as well as in private business the end, or at least the way in which the end can be reached, should be in sight from the beginning. 